\title{
"CAMBRIDGE-THEN AND NOW."*
}

\author{
By BUSHELL ANNINGSON, M.A., M.D., \\ Medical Officer of Health for Cambridge, University Lecturer in Medical \\ Jurisprudence, Secretary State Medicine Syndicate, University of \\ Cambridge; President of the Eastem Counties Branch of the \\ Incorporated Society of Medical Officers of Health.
}

WHEN the newly-constituted Eastern Counties Branch of the Society of Medical Officers of Health honoured me by electing me their first President, it became a matter of some anxiety to me to deeide on what subject I could most fittingly address them. The geographical expression "Eastern Counties," extending nearly from the Thames to the Humber, and including in its area the vast tracts of Fen-land, which between the times when Hereward the Wake held against the Normans the Isle of the Willow, and the great drainage works which led to the extinction of ague, suggested a review of the sanitary conditions prevailing through the centuries; but little consideration was needful to convince me that the magnitude of the subject was too great for me. I have, therefore, felt constrained to limit myself to the more narrow area of the University and Town where we are meeting, and to discourse awhile on "Cambridge-Then and Now." One difficulty in my path is the difference of area occupied by the ancient place and the modern. There has been here, as elsewhere, expansion and displacement, and more displacement than elsewhere, by the intermingling of the colleges with the town; if Roman influence, which has been transitory all through the country, be left out of account, the ancient town may, as Prof. Maitland conceives it, be regarded as a larger village than others, but still a village, with its messuages and common lands. The history of its evolution from this state into one essentially urban-from a vill into a civitas-is not the present object, althongh the several stages of development have had a large influence upon the life history of the dwellers therein; the conditions of living in the far past, the middle period, and the present, might be expressed by a new set of degrees of comparison as bad, worse, better (or best).

In its early period Cambridge town or vill was one of the hundreds $\dagger$ of the county, with the same sort of fields and messuages as the others.

The place has had many varieties of the present name, but the affix "bridge" is indicative of its importance, and according to Clark, "in the early middle ages the great bridge at Cambridge was the only

* Presidential Address delivered 17th June, 1905.

+ A hundred (Saxon) was so named because it expressed an area of ten titheings, and each titheing of ten households. 
point at which the river Cam could be crossed by travellers from the Eastern Counties to the Midlands, and Stourbridge Fair made Cambridge a trading centre at that time of far greater importance than it is at present."

It had the name of Grantanbryge in A.D. 875, i.e. about King Alfred's time, and in Domesday Book, Grentebrige.

Two peculiar operating factors in the municipal life of Cambridge have been :-

1. The early intrusion into its boundary of the studium, and the development of the studium into the universitas, and the subsequent attempt on the part of the university to control the municipal life of the place.

2. The circumstance of its having always been a royal demesne, subject to the King only, and, to quote Atkinson, "no lower lord"; whereby, in the struggle for municipal freedom, which was in early times going on everywhere, they obtained every privilege they desired by charter without great difficulty.

Some historians assume that Cambridge University was founded by Sebert, King of Essex, in the year 664, that is about 200 years antecedent to the alleged foundation of Oxford by Alfred; but there is little to support this assumption.

Another main cause of the early and rapid rise of Cambridge into importance beyond that of the other villages, was its position at the head of a series of waterways connecting it with the ancient port of Lynn, and with the more western counties of Huntingdon, Bedford, etc.

The Recorder of Cambridge, in his speech of welcome to King James, March, 1614, says: "Touchinge the antiquitie and denomination, historians testifie it was builded before Christ's incarnation, with a castle, towers, and walls of defence by Duke Cantaber, the Sonne of the Kinge of Spayne, who was entertained in England by King Gurguntius; and the towne being situated and united with a bridge upon the river then called Canta, was denominated Cantabridge; and in tract of tyme the name of the river being altered to Granta, the towne likewise to Grantabridge; and after it was called Cam, and the towne Cambridge. . . . This river is current throughe the heart of the Shire, with navigation to the sea, and is the life of trafficke to this towne and countie ; and no bridge is over the same but at Cambridge, and it is mantayned by fower score hides of land lyeing spavin in this Shire which are of your Majestie by pontage appropriate to this bridge only. ...

Having regard to the Cam of now, it is scarcely conceivable it could ever have been of such importance to the prosperity of the town, but 
from an incident which occurred a very few years after the visit of King James, 1649, and recorded by Badeslade, it may be gathered that the river must have been subject to tidal influences, otherwise the citizens of Cambridge and Lynn would not have so urgently protested against the construction of Denver Sluice (a lock about 12 miles below Ely), on the ground that such construction would stop the tidal wave and ruin the commerce of both towns.

"The Tide putting up fo far into all thefe Rivers and filling them twice in every twenty-four Hours, they were not only competently fupply'd with water from Sea in the drieft Seafons to ferve for the Inland Navigation, which by means of fo many Branches is the most extenfive in England, fo that Commerce and Trade was conftantly maintain'd up the River Nene to Well . . . . . And up the River Oufe they could fail with forty Tuns Freight thirty-fix Miles at leaft from Lenne at ordinary Neip-Tides; and great and conftant Commerce was held to Cambridge, Bedford, ete."*

The following is from a petition of the Mayor, Aldermen, and Common Council of the town of Lenne, in Norfolk, against the erection of the sluice :-

"For it muft be taken for granted, that the Flood cannot flow higher up the River than the Sluices, . . . . . They most humbly pray that there be no sluices set upon the river of Ouse to hinder navigation."

In the Petition of the Vice-Chancellor and heads of Colleges in the University of Cambridge, together with the mayor and aldermen of the town of Cambridge, sheweth, that whereby an Act for the draining of the great level of the Fens, bearing date 29th May, 1649, it is ordered . . . . . "that the navigation of the two rivers (Granta and Ouse), as to the conveyance from Cambridge to the town of Lenne, and from Lenne thither, will be thereby either wholly taken away or very much obstructed in regard the said river of Ouse, which by its joining itself with the river of Grant, doth many ways maintain, the said navigation will be altogether or in great part diverted to another course. As likewise the navigation between the town of Cambridge and the town of St. Ives, Huntingdon and divers others by the river of Ouse will be greatly interrupted. Whereby not only the said University and Town of Cambridge will be wholly undone, and all the adjacent countries greatly damnified and impoverish'd, but also a great prejudice will thereby befall to a great part of this whole nation, by the stoppage of the general commerce at Sturbridge fair."

* Badeslade's History of the Ancient and Present State of the Navigation of the Port of King's Lynn and of Cambridge (London: MDccxxv.), page 12. 
Denver Sluice was erected 1651, by the Corporation of Adventurers. Denver Sluice "was undermined first and afterwards blown up and destroyed by the Tides from Sea, Ano. 1713."

Whether the fears of the petitioners were justified or not, the single bridge and the water facilities did doubtless bring about the commercial importance of the place.

"I cannot omit," says Defoe, " that I came necessarily through Stourbridge Fair, which was then at its height . . . . . which is not only the greatest in the whole nation, but in the world; nor if I may believe those who have seen them all, is the fair at Leipzig in Saxony, the mart at Frankfort-on-the-Main, or the fairs at Nuremberg or Augsburg, anyway to compare to this fair at Stourbridge."

The commercial value and glory of the river Cam, and of Stourbridge Fair, have dwindled almost to extinction, and although we have still a Navigation Authority, and Stourbridge is still proclaimed by the mayor in state, yet they are both now mainly given over to amusement and sport, not by the way altogether without value, for the physical training and bodily discipline of rowing are certainly valuable, and even cocoa-nut shying may be a good training in accuracy of eye and deftness of -hand. Four railways now connect Cambridge with other places, and have supplanted in object both the river and the fair.

Not merchants alone, it may be assumed, would resort to this great annual gathering, which was opened with much municipal pomp, but from the monasteries, which were so great and so numerous in this Fen-land, the masters of the novices would also come to lecture, and so gather round them bands of students ; later the itinerant character of the teaching merges into some local and permanent system, with some directing head such as Rector; organization and specialization follow; and in the exact words of Mr. J. W. Clark, "the place gains reputation as a studium, and the little body of volunteers is saluted as Universitas Vestra." The evolution of the University and its Colleges as we now know them, is not however my present object.

Besides merchants and students, Stourbridge Fair was then an importer and distributor of Mediæval plagues, just as now, dwindled as it is, within my own experience it has brought to us small-pox, typhoid fever, and diphtheria. In Cooper's Annals are many references to the presence of plagues in Cambridge, sometimes for several successive years together, and one such is mentioned as being directly the result of the foregathering at Stourbridge Fair.

Another visitation of a plague, which was probably typhus (for the records give but little indication as to the real diagnosis of the prevailing sickness), occurred in 1521-2, and it is recorded that:-

"In thys year of the Assize kept at the Castle of Cambridge in Lent, 
the justices and all the gentlemen, bailiffs, and others resorting thereto, toke such an infection, and many died, and almost all that were present were sore sicke and narrowly escaped with their lives."

Also that "The old parish of All Saints, at the Castle, has had no separate existence since the 14th Century, when the Black Death carried off almost the whole of its population. The church fell into ruins. It appears to have been situated on the south side of Huntingdon Road, and to the west of Mount Pleasant, on a spot now a garden, surrounded by a high brick wall."

That is what happened to the parishes and churches. Here is what happened to the clergy :-

"The mortality among the clergy was immense. In the year of the great sickness (1349), the appointments to livings rose to 97 , chiefly in the month of July. The recurrence of such visitations all through the middle ages was very frequent, but the records of the later visitations are the fullest."

And this is what happened to the doctors.*

"The plague again broke forth in Cambridge (1629). The university ... was dissolved, and scholars dispersed into the country; three hundred and forty-seven of the townspeople died of the infection. But this corruption of the air proved the generation of many doctors, graduated in a clandestine way without keeping the Acts, to the great disgust of those who had fairly gotten their degrees with pains and expense. Yea, Dr. Collins being afterwards to admit an able man doctor, did (according to the pleasantness of his fancy), distinguish ' inter cathedram pestilentice et cathedram eminentice,' leaving it to his auditors to apprehend his meaning therein." $\dagger$

Not a few times through the centuries Stourbridge fair and Midsummer fair have been prohibited by royal command; and it is recorded how frequently, on account of plague, the University had to suspend its scholastic work for lengthened periods, or migrate into the country. The university was thus almost entirely deserted, all Acts in university and college were suspended, and leave of absence granted to every one without loss of stipend or other privileges, so that, as one of our annalists (Gostlin) says "Nec Academiam in Academia nec Cantabrigiam in Cantabrigia videre licuit aut invenire." For the few whom duty or poverty forced to remain, special regulations were made as follows :

"That yf it please God that any in the College should be visited with the pest, that convenient nurses, physicke, and advice be provided for them. . . That the cook and his family be received into the

* Fuller's History of the University of Uambridge, 1629.

+ Fuller, p. 314. 
College to provide commons for those few, which should venture to stay; and that Miles and a Scholar be in the Butteryes. That all the Bedmakers, except two, be immediately turned out of the College, and be allowed two shillings apiece every weeke. That a man be hired for 5s. a week for attending continually at the gate to goe of errands into the town."

In the year 1575 Dr. Pern, Master of Peterhouse and Vice-Chancellor, together with Roger Stegge, Mayor. promulgated a set of rules for the sanitary government of the town, and for the isolation of infected. persons, and for the destruction of infected goods. These are far too long for quotation, though I shall have occasion to refer to them later. One extract will suffice :-

"Also that no manner of person inhabiting within any house visited. with plague or pestilence, after notice given by the Vice-Chancellor and Mayor, by these words in writing in great letters set upon the uppermost post of his street door, viz : 'LORD HAVE MERCY UPON US,' shall go abroad out of that house upon pain for the first default 20 s., and for the second default herein, $40 \mathrm{~s}$., and for the third default perpetual banishment out of the town."

It is most interesting to note here that one of the most beautiful architectural features in Cambridge-Clare Bridge-is one of the several beneficial results of plague prevalence, as indicated by the petition of the Masters and Fellows of Clare Hall in the year 1673 to King Charles as follows:-

".... Your petitioners doe humblie begg of your most sacred Matie $y^{t}$ they may be suffered at their own chardge to land a bridge over ye river, and enjoy a passadge through ye said But-Close into ye feilds, $\mathrm{w}^{\mathrm{ch}}$ would be little or noe prejudice to them, and of great benefitt to your petitioners, especially in tymes of infection, having noe passadge into ye feilds but through ye Chappell yard of your said Kings Colledge, ye gates whereof are shutt up in those tymes of danger."

Further wishing to obtain for the same purpose land belonging to King's College on the west bank of the river, they offered as a further inducement to King's, that they would set back their proposed new building, which was to be exactly opposite the building of King's Hall, some $70 \mathrm{ft}$., whereby their buildings would get more light and air, and "ye annoyance of ye windes gathering between ye Chappell and our College" would be removed.

"In the parish books are charges for pitch and tar to burn in the churches."*

From all the above, it would appear that segregation and disinfection of a sort were practised then as now, but not in the same measure of 
efficiency and success as in our days. Neither was the community altogether ignorant or careless of the value of cleanliness, fresh air, and pure food and water; but they had not a complete knowledge, nor the means of carrying into effect the little knowledge that they did possess. Sanitary knowledge and the ability to use it have come only within the Victorian era, and may be assumed to start with Chadwick's Health of Towns Commission. It is likely enough that the sanitary condition of Cambridge in very early times, when the monks of Ely had a grant of fishery here, was much better than it subsequently became; there were then no sewers to pollute the river; little slop-water to pollute the soil; and the inhabitants too few to pollute the air.

The first incentive to pollute the river was the construction by Henry III. (1266) of a ditch first called the "King's Ditch," but subsequently the "Black Ditch"; it encircled that part of the ancient town not bounded by the river, and commencing above "Small Bridge," near what is now "Silver Street," and traversed Mill-lane, then past Pembroke College, across the old Botanic Garden (now the site of the New Museums), and Tibbs Row, to Christ's College, past Sidney Sussex College, down Sidney Street (then Conduit Street), to the Great Bridge opposite Magdalene College; it is supposed it was for a military fosse, for it would appear that on account of the troubles of the times the King intended to have built also a rampart along the line of the ditch, but time and opportunity failed him.

In the following year, 1267, probably at the time of his visit, the King granted Cambridge its second important Charter, and among its provisions is one to the following effect:-_" That the town should be cleansed from dirt and filth, and kept clean ; and that the watercourse should be opened and kept open as of old it was used, so that filth might run off. That all obstacles which prevented the passage should be removed, and that the great ditch of the town should be cleansed, for doing whereof two of the more lawful burgesses in every street, were to be sworn before the Mayor and Bailiffs (the Chancellor and Masters being asked to be present if they would)." A relic of this duty of the burgesses remained till quite recently in the obligation of each householder to clean snow from the pavement in front of his dwelling. The foul condition of the streets in King Henry's charter was in a large measure due to the practice of housing cattle, swine, and horses within the town of a night, and commoning them by day on the town pastures; for at this time the place was still an agricultural unit of the county, and had not yet become a "township." The right of depasturage of cattle and horses on the commons still persists.

In Cooper's Annals, volume 1, pages 133 and 134, we find the following:- 
"The thirteenth chapter in old records frequently termed the Statute of Cambridge was in all probability suggested by the filthy state in which the town appears to have been about this period, when the King held his Parliament here in 1388."

It is recited in the Statute: "That so much dung and filth of the garbage . . be cast and put in ditches, rivers, and other waters, etc. . . . that the air there is greatly corrupt and infect, and many maladies and other intolerable diseases do daily happen. ..."

Excremental nuisances were not much better in and about the colleges. From Lamb's Corpus Documents, page 156, it would appear:

"That the seyde College (Trinitie) doth commonly use to laye their mucke and meanor on the back apon the forseyd common grene when they will suffer no man elles to do the like, and have builded a common Jakes upon the same."

From Grace Book B., we find the following item :-

"Pro mundacione bocardi ijs viijd." (2s. 8d.)

N.B.-Bocardi were the "places of Easment."

Excremext Disposal.-In Cooper's Annals, vol. 11, pages 332, 333, 334 , it is recorded:-

"On the 30th Sept., 1575, a composition was made between the University and town for cleansing and lighting the streets, preventing the various nuisances, and diminishing the danger of pestilence. 'Forasmuch as the ordinance and provision made in the composition between the university and the town of Cambridge, for correction of common nuisances, taketh no good effect, and that divers evil disposed persons inhabiting within this town do suffer their cannels to lye uncleansed, and also lay their muck, mire, dung, and filth, in the high streets, under colledge walls, and other lanes, within the town, to the great noyance of all students, people of the town, and strangers. Also it is agreed by the said Mayor, bailiffs, and burgesses, that the void ground by Newnham Mills, the ground at the south end of Spital House, the fair yard, the hill in the end of Jesus Lane, the valley beyond the Castle Hill, and the Padding Pits, shall be the common dung hills and places, to lay the muck, mire, and filth, within the town as is aforesaid."

For the double purpose of cleansing the Black Ditch, otherwise King's Ditch, and bringing pure water to the town, it occurred to Dr. Pern, Master of Peterhouse and Dean of Ely, in 1574, to bring water in open conduit from the "Nine Wells," a chalk spring at Great Shelford, to Cambridge. No action, however, followed his suggestion till the idea was revived by the first master of Sidney Sussex College, in 1610 , and carried into effect at the joint expense of the town and university, according to a scheme devised by Edward Wright, M.A., of Gonville and Caius College. 
Before making a natural transition to the subject of water supply let us glance for a few moments on further developments of the sewage and excremental disposal. As the town grew in population, and built-on area, the difficulties increased, and more or less imperfect schemes were adopted in consequence of continued friction between the town and university on the question of drainage. An Act of Parliament was obtained, called the "Cambridge Improvement Act," for the better drainage etc. of the town, but notwithstanding the attitude assumed by the university on the question, many of the riparian colleges continued to have "dropping places," or large sewers of their own communicating direct with the river. The Commissioners created by the Act certainly redrained the town, but it turned out unsatisfactory, and there was no method of scavenging for household refuse even at the time of my own appointment here. We now have a complete new system of sewerage, a pumping station with rising main to convey the sewage on to land and contactbeds, a system of scavengering, a "destructor" for burning all the waste garbage produced; thus the river has been relieved of a function which it should never have had.

There is little to say about the water supply of bygone times; I have already adverted to the scheme of bringing water from the "Nine Wells;" it now goes by the name of Hobson's Stream and Conduit, and supplies the present fountain on the Market Hill.

The Grey Friars, now Sidney Sussex College, brought water from a gravel bed on high ground at Madingley; this water became intercepted by Trinity college, and the fountain in the Great Court is still supplied from that source. For the rest, the colleges and town depended on surface wells; and a glance at Loggan's views, and others of the ancient town, show pumps in college quadrangles, and in the public streets, mostly against the churchyard walls.

From Cambridge Portfolio, 318:-

"Henry VI. in his will directs that in the middle of the great quadrant of Kings College "shall be a conduit goodly devised for the ease of the said college,' and for this purpose gave license to the Convent of Barnwell to grant a piece of land called 'Holwelle,' situate at Madingley, near the Grange belonging to the convent of Morrbans, for the subterranean aqueduct to be made thence to the college.

"There was also the King's Hall Conduit, from which Henry VI. had before 1450 granted to that college 'a voide place of ground' being near it.

"The conduitnow standing in the great court of Trinity College in all probability occupies the place of one which had belonged to King's Hall. It was apparently built about the reign of James I." 
So it would appear that this enterprising college, which had already absorbed Michael House, belonging to that society, and Physicke Hostel, belonging to Gonville Hall, got its wate= from the Grey Friars, and its fountain from King's Hall. Now King's College has erected in their new court a new fountain, but the water is from the same source as that for the vulgar use of all who choose to buy it; this vulgar water supply is one of the best things that exists now, and did not so then; it is nearly the same as the chalk water from the "Nine Wells," but the company mix with it a certain proportion of water from the greensand. Nearly every household is now supplied with this excellent water, which is delivered on the constant system and at high pressure. It is not, however, many years ago that a group of little streets near the conduit head derived their water from Hobson's Stream, but the ambitious little village of Great Shelford desired to become modern in the sanitary sense, and began to cast their slop water, etc., into a tributary of the Hobson's Stream.

But water now-a-days is used for more purposes than drinking; our wise ancestors however valued it too much to permit of its serving any other purpose, and on the 8th of May, 1571, the following edict was made, as quoted in Cooper's Annals, (vol. 2, p. 277):"Dr. Whitgift, Vice-Chancellor, and the heads of colleges, for many and weighty reasons decreed, that if any schollars should go into any river, pool, or other water in the county of Cambridge, by day or by night to swim or wash, he should, if under the degree of Bachelor of Arts, for the first offence be sharply and severely whipped publicly in the common hall of the college in which he dwelt, in the presence of all the fellows, schollars, and others dwelling in the college, and on the next day should be again openly whipped in the Public School where he was or ought to be an auditor, before all the auditors, by one of the proctors or some other assigned by the Vice-Chancellor, and for the second offence every such delinquent should be expelled his college and the university for ever. But if he should be a Bachelor of Arts, then for the first offence he should be put in the stocks for a whole day in the common hall of his college, and should before he was liberated pay $10 \mathrm{~s}$. towards the commons of the college, and for the second offence should be expelled his college and the university; and if he should be a Master of Arts, etc., he should be severely punished at the judgment and discretion of the Master of his college, etc. Dr. Peacock characterizes this as a "decree of savage and indecent severity."

Now we swim in our river and drink from its head waters.

My short sanitary back-look would be incomplete were I not to give a glance, and time indicates it must be but a glance and nothing more, at the relation of people to air-space. The ancient guild merchants 
did undesigned sanitary service by their active opposition in their commercial interest to overcrowding of the town.

"In the days of Elizabeth and her two next successors," says Maitland, "there was a scare at Cambridge, as elsewhere, about overcrowäing."

"The poore persons dwelling in cottages and divided tenements are suffered to enjoye the bennifitt of the commons, and when the Magistrats have offered to keepe them off, by force they have putt on their cattell, and this liberty of commonage and tollerance of the Magistrate hath much increased of poore amongst us." Et. Seq.

And then a sort of Aliens Bill was devised to exclude them.

Then the University began to complain of the townsfolk assuming to themselves rights, which they asserted King John's Charter never intended:-

"Seeing this colour of being lords of the soyle encourageth them to build and pester every lane and corner of the towne with unholsome and base cottages, which receive none but ydle and poore distressed people, that live and pray upon the University."

On the other hand, the intrusion, as I have ventured to call it, of the University and Colleges into the town has led to large displacement of these same " unholsome and base cottages." Witness the expansions of King's and Trinity.

As a sequence of it all, there is now scarcely a town in England that has so much open space, private as well as public, as has Cambridge.

A few words in conclusion on the condition of life in this regard in the Colleges. Some misconception exists in the minds of many visitors to our Colleges with regard to the small cubic capacity of the sleeping apartments of the undergraduates in the more ancient parts of the Colleges. The late Prof. Willis, of Caius, worked out the real meaning of the present condition of things, and found by examination of the College records that several students occupied one large room, wherein they lived and slept, and had for seclusion as private studies small partitioned-off spaces, somewhat like cupboards, in the corners of the room, each having a window. These exist now, but in accord with the present practice of students not living in groups, these small spaces are made use of for the combined purpose of sleeping and dressing; therefore it is unfair to criticize these partitioned-off spaces as if they were originally designed as sleeping apartments.

Pressure of time has prevented me from making use of all the interesting historical material concerning the Town and University. I have, therefore, attempted a mere sketch, as concisely as possible, of the sanitary conditions of life here in the past and the present, and hope it has not been altogether uninteresting to you. 